kurven in der Abb. 3 vorliegt. Dieses Niveau wird für $\mathrm{D}$ (in der $\mathrm{Abb}$. punktiert gezeichnet) niedriger liegen als für $\mathrm{H}$ und die verschiedenen Verteilungen in Abhängigkeit vom $\mathrm{O}(\mathrm{H}) \ldots \mathrm{O}$-Abstand werden den in der Abbildung veranschaulichten ähneln.

Sowie das niedrigste Schwingungsniveau für $\mathrm{H}$ sich der Barrierenspitze nähert, werden die Unterschiede zwischen den Verteilungen von $\mathrm{H}$ und $\mathrm{D}$ so groß, daß $\mathrm{H}$ eine beträchtlich höhere Dichte als D im Zentrum des Doppelminimum-Potentials besitzt. Die Dichte von $\mathrm{H}$ im Zentrum der Brücke wird beide O-Atome anziehen, was dann zu einer Verkürzung der Wasserstoffbrücken-Bindungslänge führt. Da D eine kleinere Dichte in der Mitte der Wasserstoffbrücke besitzt, wird in der ODO-Gruppierung die Anziehung der O-Atome geringer sein. Deshalb sollte gerade in diesem Bereich, wo die Unterschiede in der Dichte von $\mathrm{H}$ und $\mathrm{D}$ besonders groß sind, der anomale $\mathrm{H}$ - D-Isotopeneffekt am größten sein, mit einem kürzeren $\mathrm{O}(\mathrm{H}) \mathrm{O}$-Abstand im Vergleich zum
O (D) O-Abstand. Der kürzere O (H) O-Abstand zieht eine niedrigere Potentialbarriere nach sich. Der längere $\mathrm{O}$ (D) $\mathrm{O}$-Abstand führt zu einer noch höheren Potentialbarriere für $\mathrm{D}$, was die Unterschiede zwischen der Dichte von $\mathrm{H}$ und $\mathrm{D}$ im Zentrum der Bindung und somit auch den anomalen $\mathrm{H}-\mathrm{D}$-Isotopeneffekt noch weiter erhöht.

Wahrscheinlich ist die Situation bei leicht asymmetrischen Doppelminimum-Potentialen ähnlich. Ein solcher Fall dürfte bei der kubischen Metaborsäure vorliegen, bei der die Umgebung von $\mathrm{O}_{\mathrm{I}}$ und $\mathrm{O}_{\text {II }}$ etwas verschieden ist. Der bei $\gamma-\mathrm{HBO}_{2}$ gefundene anomale $\mathrm{H}-\mathrm{D}$-Isotopeneffekt wird daher auf der Grundlage einer verschiedenen Dichte von $\mathrm{H}$ und D im Zentrum eines Doppelminimum-Potentials für die Wasserstoffbrücken-Bindung gedeutet.

Herrn Professor Dr. O. Glemser danken wir sehr für die Förderung dieser Arbeit, der Deutschen Forschungsgemeinschaft und dem Fonds der Chemischen Industrie für die Bereitstellung von Sachmitteln.

\title{
Potentiometric Study on the Composition and Stability of Beryllium Complexes of 3,5-Dinitrosalicylic Acid
}

\author{
S. S. DubE and S. S. DHINDSA \\ Department of Chemistry, Government College, Kota (Rajasthan)/India \\ (Z. Naturforschg. 24 b, 967-970 [1969] ; eingegangen am 10. März 1969)
}

\begin{abstract}
The complexation of beryllium(II) with 3,5-dinitrosalicylic acid in aqueous $0.1 \mathrm{M} \mathrm{KNO}_{3}$ medium has been investigated potentiometrically, which evince the formation of $1: 1$ and $1: 2$ complexes, predominating in the $\mathrm{pH}$ ranges $2.7-4$ and $4-9$, respectively. The values of $\log K_{1}$ and $\log K_{2}$, determined by alternative methods, have been found to be 7.13 and 5.29 respectively. The value of overall change in free energy $(\Delta F)$ accompanying the reaction has been found to be -17.34 $\mathrm{Kcal} /$ mole at $35^{\circ} \mathrm{C}$.
\end{abstract}

3,5-Dinitrosalicylic acid (3,5-DNS) figures prominently in the discussion of hydroxy carboxylic acids and provides two possible coordination sites, viz., $-\mathrm{OH}$ and $-\mathrm{COOH}$ groups, which have attracted the attention of many workers to explore its interaction with various bivalent and trivalent metal ions like, $\mathrm{Ni}^{1}, \mathrm{Co}^{1}, \mathrm{Al}^{2}, \mathrm{Ga}^{2}$, and $\mathrm{In}^{2}$. A survey of the literature reveals the absence of any study on the system Be-3,5-DNS. The present investigation has, therefore, been initiated with a view to make a detailed study of the system involving the computation of the true stability constants by alternative

1 S. S. Dube and S. S. Dhindsa, Indian J. Chem., in press. methods (spreading factor method, convergence formulas of successive approximation, correction term method, least square treatment, and method of successive approximation) and the determination of overall change in free energy accompanying the reaction.

\section{Experimental}

AnalaR (B.D.H.) reagents beryllium sulphate, potassium nitrate, sodium hydroxide and Riedel's (Germany) 3,5-DNS, were used and their solutions prepared in air free conductivity water.

2 V. I. KuZnetsov and N. N. BASARgin, Zh. Neorgn. Khim.
7, $814[1962]$. 
A Cambridge bench pattern (null-deflection type) $\mathrm{pH}$ meter was used for $\mathrm{pH}$ measurements. A glass electrode of the range $0-14 \mathrm{pH}$ calibrated frequently by using buffer solutions of different $\mathrm{pH}$ values, was used in conjunction with a saturated calomel electrode connected to the cell by a low resistance salt bridge. The temperature was controlled by an electrically maintained thermostat.

The experimental procedure consists in performing a series of $\mathrm{pH}$ titrations of $3,5-\mathrm{DNS}$ with standard $\mathrm{NaOH}$ in the absence and presence of $\mathrm{Be}$ (II) at various ligand to metal ratios, viz., $1: 1,2: 1$ and $3: 1$. The CaLvin and MELCHIOR's ${ }^{3}$ extention of BJERRUM's ${ }^{4}$ method was used to calculate the stability constants of the complexes formed and these were refined by alternative methods.

\section{Results and Discussion}

To establish the stoichiometry of the complex species formed during the interaction of beryllium with 3,5-DNS, the magnitude of proton displacement was determined by titrating the solutions containing metal and ligand in different ratios against standard alkali. The titration curves are shown in fig. 1 .

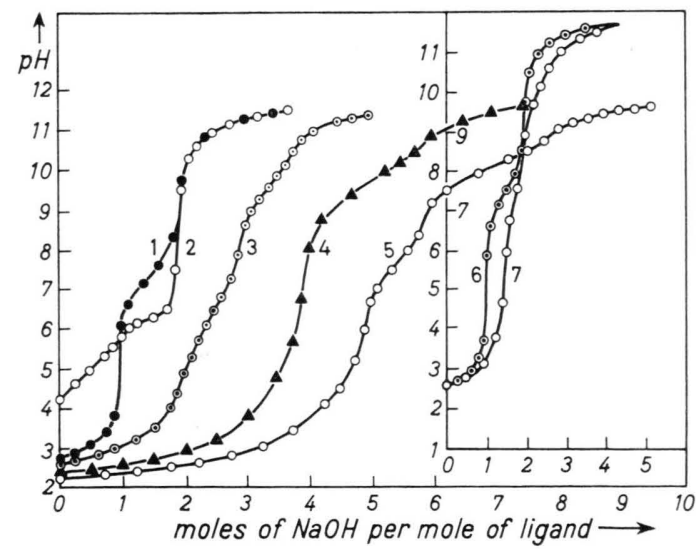

Fig. 1. Potentiometric titration curves of beryllium in the absence and presence of 3,5-DNS against $0.1 \mathrm{M} \mathrm{NaOH}$. Curve 1, $4.0 \times 10^{-3} \mathrm{M} 3,5$-DNS; curve $2,4.0 \times 10^{-3} \mathrm{M} \mathrm{Be}(\mathrm{II})$; curve $3,4.0 \times 10^{-3} \mathrm{M} 3,5$-DNS $+4.0 \times 10^{-3} \mathrm{M} \mathrm{Be}(\mathrm{II}) ;$ curve 4 $8.0 \times 10^{-3} \mathrm{M} 3,5$-DNS $+4.0 \times 10^{-3} \mathrm{M} \mathrm{Be}(\mathrm{II}) ;$ curve $5,1.2 \times$ $10^{-2} \mathrm{M} 3,5$-DNS $+4.0 \times 10^{-3} \mathrm{M} \mathrm{Be}(\mathrm{II})$; curve $6,5.0 \times 10^{-3} \mathrm{M}$ 3,5-DNS; curve 7, $5.0 \times 10^{-3} \mathrm{M} 3,5$-DNS $+1.25 \times 10^{-3} \mathrm{M}$ $\mathrm{Be}(\mathrm{II})$.

The appearance of inflections after the addition of one and two moles of base/mole of ligand (curve-1) correspond respectively to the neutralization of carboxyl and phenolic groups. Curve-2 shows the interaction of $\mathrm{Be}(\mathrm{II})$ with $\mathrm{NaOH}$ in the

3 M. Calvin and N. C. Melchior, J. Amer. chem. Soc. 70, 3270 [1948]. absence of ligand. Addition of an equimolecular concentration of beryllium (curve-3) appreciably alters the shape of free ligand titration curve, as a result of complex formation and hence a considerable lowering in the buffer region is indicated. The simultaneous neutralization of carboxyl and phenolic groups indicates the formation of an uncharged $1: 1$ complex as under:

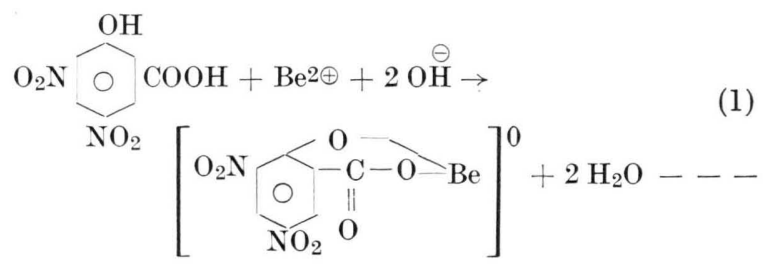

On further addition of alkali, a second inflection at three moles of base/mole of ligand is observed, which may be attributed to the disproportionation of $1: 1$ complex into more stable $1: 2$ complex and beryllium hydroxide. The appearance of the turbidity in this range of titration supports the above view. The possible reaction is indicated below:

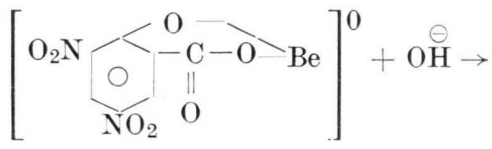



Addition of alkali beyond three moles of base/ mole of ligand changes considerably the colour of the titre from yellowish white to dark yellow (colour of the disodium salt of 3,5-DNS) and causes a third inflection at four moles of base/mole of ligand. This abnormal observation may be due to the decomposition of $1: 2$ complex at higher $\mathrm{pH}$ values into beryllium hydroxide and disodium salt of 3,5 -DNS. The reaction may be represented as:



\footnotetext{
${ }^{4} \mathrm{~J}$. Bjerrum, Metal amine formation in aqueous solutions. P. Haase and Co., Copenhagen 1941.
} 
When solutions containing metal and ligand in the ratio of $1: 2$ was titrated against $\mathrm{NaOH}$, two inflections were obtained (curve-4), first at four moles of base/mole of ligand indicating the formation of $1: 2$ complex,

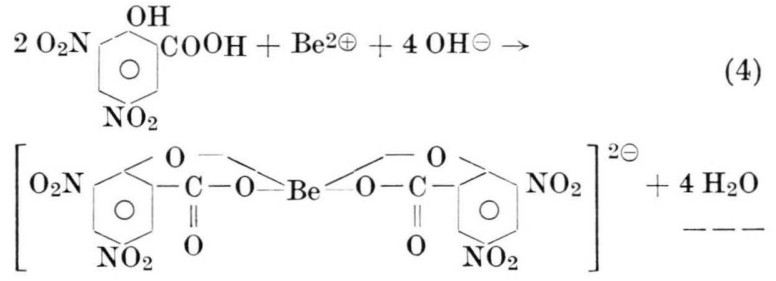

of ligand with change in colour of the titre, indicates the decomposition of the $1: 2$ complex into beryllium hydroxide and disodium salt of $3,5-\mathrm{DNS}$ as indicated by equation (3).

When three moles of 3,5-DNS are added to a single mole of beryllium (curve-5), two inflections at 5 and 6 moles of base/mole of ligand are indicated. The first inflection corresponding to the formation of $1: 2$ complex and neutralization of $-\mathrm{COOH}$ group of the third mole of the ligand and the second inflection corresponding to the neutralization of $-\mathrm{OH}$ group.


$+\underbrace{\underset{\mathrm{O}}{\mathrm{O}}}_{\mathrm{O}_{2} \mathrm{~N}} \underset{\mathrm{OH}}{\mathrm{OH}} \mathrm{COO} \ominus+5 \mathrm{H}_{2} \mathrm{O}---$

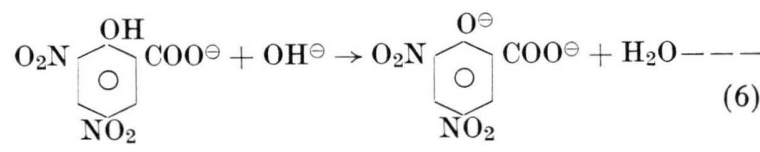

The complex decomposes into disodium salt of 3,5-DNS and beryllium hydroxide on further addition of $\mathrm{NaOH}$ and a weak inflection at 8 moles of base/mole of ligand is indicated.

$$
\text { Stability constants }
$$

The Calvin and Melchior's extention of B j errum's method was used to calculate the stability constants of the complexes formed from poten- tiometric titration data. The reaction of the complex formation may be represented by equations (7) and (8)

$$
\begin{aligned}
\mathrm{Be}^{2 \oplus}+\mathrm{A}^{2 \ominus} \rightleftharpoons \mathrm{BeA}, \\
\mathrm{BeA}+\mathrm{A}^{2 \ominus} \rightleftharpoons \mathrm{BeA}_{2}{ }^{2} .
\end{aligned}
$$

The overall stability constant $\beta$ is given by:

$$
\beta=\frac{\left[\mathrm{BeA}_{2}{ }^{2}\right]}{\left[\mathrm{Be}^{2 \oplus}\right]\left[\mathrm{A}_{2}^{2 \ominus}\right]^{2}}=K, K_{2}
$$

where $K_{1}$ and $K_{2}$ are the formation constants of reactions 7 and 8 .

The $\bar{n}$ values (average number of ligand molecules bound per metal ion) were calculated from fig. 1, (curves 6 and 7), which represents the potentiometric titrations of 3,5-DNS with standard alkali in the absence and presence of $\mathrm{Be}^{2 \oplus}$ at $35^{\circ} \mathrm{C}$. At any $\mathrm{pH}$, the horizontal distances between curves 6 and 7 , measures quite accurately the additional base consumed or the total number of $\mathrm{A}^{2 \ominus}$ complexed. This number divided by total $\mathrm{Be}^{2 \oplus}$ is $\bar{n}$. At any $\mathrm{pH}$, $\left[\mathrm{A}^{2 \ominus}\right]$ was calculated as :

$$
\left[A^{2 \ominus}\right]=\frac{\left[\mathrm{H}_{2} \mathrm{~A}\right]_{\text {Total }}-[\mathrm{BeA}]-2\left[\mathrm{BeA}_{2}{ }^{2 \ominus}\right]}{\frac{\left[\mathrm{H}^{\oplus}\right]^{2}}{\mathrm{~K}_{1} \mathrm{~K}_{2}}+\frac{\left[\mathrm{H}^{\oplus}\right]}{K_{2}}+1}
$$

where $K_{1}$ and $K_{2}$ are the first and second dissociation constants of the acid. The $p \mathrm{~K}_{1}$ and $p \mathrm{~K}_{2}$ values determined $^{5}$, are 2.96 and 7.61 respectively. All quantities in equation (10) are known and thus a series of $\bar{n}$ and $\left[\mathrm{A}^{2 \ominus}\right]$ values at varoius $\mathrm{pH}$ levels were obtained and formation curve was plotted. Fig. 2 is the plot of $\bar{n}$ against $-\log \left[\mathrm{A}^{2 \ominus}\right]$. From the graph the values of $\log K_{1}$ and $\log K_{2}$ were determined by the following different methods:

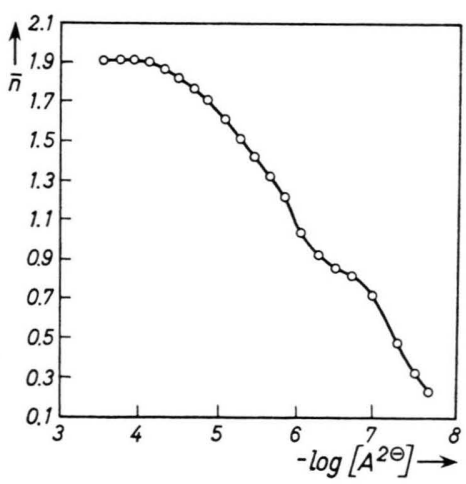

Fig. 2. Plot of $\bar{n} \mathrm{v} / \mathrm{s}-\log \left[\mathrm{A}^{2 \ominus}\right]$.

5 S. S. Dube and S. S. Dhindsa, Curr. Sci., 37 (12), 642 [1968]. 
1. Interpolation at half $\bar{n}$ values. 2. Spreading factor method. 3. Correction term method. 4 . The convergence formulas of SCHRODER ${ }^{6}$ for successive approximation. 5. Least square treatment. 6. Method of successive approximation ${ }^{7}$.

\begin{tabular}{lccc}
\hline & $\log K_{1}$ & $\log K_{2}$ & $\log \beta$ \\
\hline 1. Interpolation at half $n$ values & 7.25 & 5.35 & 12.60 \\
2. Spreading factor method & 6.96 & 5.24 & 12.20 \\
3. Correction term method & 7.20 & 5.41 & 12.61 \\
4. Convergence formulae & 7.23 & 5.37 & 12.60 \\
5. Least square treatment & 6.95 & 4.92 & 11.87 \\
6. Method of successive & & & \\
$\quad$ approximation & 7.23 & 5.49 & 12.72 \\
$\quad$ Mean & 7.13 & 5.29 & 12.42 \\
\hline
\end{tabular}

Table 1. Values of formation constants by different methods.

${ }^{6}$ K. H. Schroder, Acta chem. scand. 20, 1401 [1966].

7 H. IRving and H. S. RossotTi, J. chem. Soc. [London] 1953, 3397.
The value of overall change in free energy $(\Delta F)$ on complex formation has been determined at $35^{\circ} \mathrm{C}$. The expression

$$
\Delta F=-R T \ln \beta .
$$

relating overall stability constant $\beta$ to the total free energy change of the reaction was employed for evaluating the values of $\Delta F$ which was found to be $-17.34 \mathrm{Kcal} / \mathrm{mole}$.

The present investigation clearly reveals the formation of $\mathrm{BeA}$ and $\mathrm{BeA}_{2}{ }^{2}{ }^{\ominus}$. The values of $\log K_{1}$ and $\log K_{2}$ were found to be 7.13 and 5.29 respectively. The value of $\Delta F$ was found to be $-17.34 \mathrm{Kcal} /$ and the second inflection at six moles of base/mole mole.

The authors wish to thank Dr. M. L. Mittal for many helpful suggestions and to the University Grants Commission for the award of a research scholarship to one of them (S. S. DHINDSA).

\title{
Spektroskopisches Verhalten von o-substituierten Arylvinylpyryliumperchloraten
}

Spectroscopic Behaviour of $o$-substituted Arylvinylpyrylium Perchlorates

G. Arnold, G. PaAl und H.-P. Vollmer

AEG-TELEFUNKEN Forschungsinstitut, Ulm

(Z. Naturforschg. 24 b, 970-972 [1969] ; eingegangen am 19. April 1969)

\begin{abstract}
The influence of the substituents on the characteristic infrared absorption frequencies and the wavelength of the absorption band in the visible region of $o$-substituted 2 [ $\beta$-n-amyl-styryl]-l-benzopyrylium perchlorates and $3[\beta$-n-amyl-1-naphthylvinyl] naphtho[2.1-b]pyrylium perchlorates has been investigated. The observed structural changes have been discussed as a function of the mesomeric effect of the substituents.
\end{abstract}

Im Zusammenhang mit Spiropyran-Synthesen wurden $o$-Hydroxy-Arylvinyl-pyryliumperchlorate präpariert $^{1}$. Sie besitzen eine starke Absorption im Sichtbaren. Die Lage dieser sogenannten Farbbande ist teilweise vom umgebenden Medium abhängig. Um festzustellen, in welchem Maße der $o$-HydroxySubstituent für die Lage der Farbbande verantwortlich ist, soll nachfolgend der Einfluß des o-Substituenten auf die Farbbande und auf die für das Pyryliumsystem charakteristischen IR-Absorptionen untersucht werden. Für diese Untersuchungen werden $o$-substituierte 2-[ $\beta$-n-Amyl-styryl]-1-benzopyryliumperchlorate (1) und 3-[ $\beta$-n-Amyl-1-naphthylvinyl]naphtho[2.1-b] pyryliumperchlorate (2) herangezogen, deren Synthese analog zu l. c. ${ }^{1}$ erfolgte.

1 C. Schiele, A. Wilhelm, D. Hendriks, M. Stepec u. G. PAAL, Tetrahedron [London] 24, 5029 [1968].



(1)

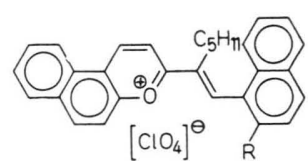

(2)
$\mathrm{R}=-\mathrm{OH},-\mathrm{OCH}_{3},-\mathrm{H},-\mathrm{OCOH}_{3}$

Zur Aufnahme der IR-Spektren mit einem BeckmanDoppelstrahlspektrometer IR-7 wurden die Pyryliumperchlorate mit $\mathrm{KBr}$ verpreßt. Die Wellenlängen der Farbbande wurden in Methanol/1-n. $\mathrm{HClO}_{4}$ $(9: 1)$ mit einem Perkin-Elmer-Spektrophotometer 137 UV bestimmt.

\section{Diskussion der Ergebnisse}

Die charakteristischen IR-Absorptionsfrequenzen und die Lage der Farbbande sind für die Verbin- 